\title{
USER INTERFACE DESIGN IN DISTANCE LEARNING SYSTEM
}

\author{
KARUOVIC, D. \& RADOSAV, D.
}

Abstract: The main aim of this paper is to indicate a statistically significant possibility of raising the overall level and quality of the education process by use of interactive educational software. The paper presents the results of researches in the field of interactivity between children and computers. The created user interface model is based on Fitts' Law. Those have experimentally been used in software, which is tested by the preschool children in Vojvodina region. This study term paper presents a new method of Fitts' rule application. They are applicable in the field of creating user interface in educational software aimed at children aged 6 or 7.

Key words: software, education, user interface
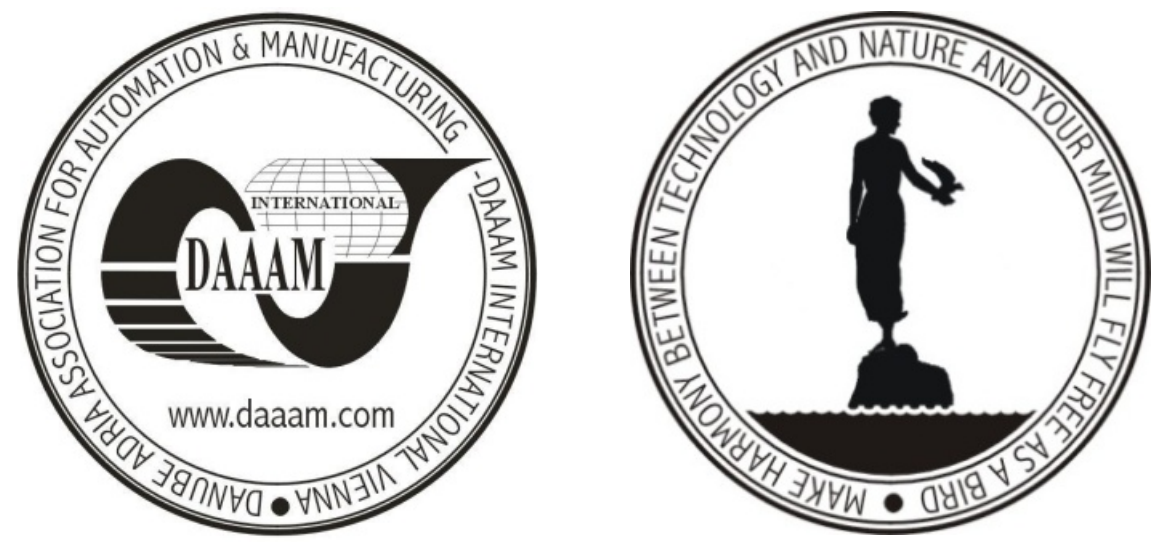

Authors' data: Mr. Sc. Karuovic, D[ijana]; Univ.Prof. Dr.techn. Radosav, $\mathrm{D}$ [ragica]; University of Novi Sad, Technical faculty "Mihajlo Pupin", Djure Djakovica St., Zrenjanin, Serbia, aruena@tf.zr.ac.yu,radosav@tf.zr.ac.yu

This Publication has to be referred as: Karuovic, D[ijana] \& Radosav, D[ragica] (2009). User Interface Design in Distance Learning System, Chapter 08 in DAAAM International Scientific Book 2009, pp. 061-070, B. Katalinic (Ed.), Published by DAAAM International, ISBN 978-3-901509-69-8, ISSN 1726-9687, Vienna, Austria DOI: $10.2507 /$ daaam.scibook.2009.08 